\title{
Surveillance of persons who tested negative for COVID-19 in Ontario, January 22-February 22, 2020
}

\author{
Michelle Murti ${ }^{1,2 *}$, Michael Whelan ${ }^{1}$, Andrea Saunders ${ }^{1}$, Karin Hohenadel ${ }^{1}$, Jonathan Gubbay ${ }^{1,3}$, \\ Sarah Buchan ${ }^{1,2}$
}

\begin{abstract}
As of January 22, 2020, "disease caused by a novel coronavirus" became a reportable disease of public health significance in Ontario. Public health units were provided with guidance on the entry of patients tested for severe acute respiratory syndrome coronavirus-2 (SARS-CoV-2), the virus causing 2019 coronavirus disease (COVID-19), into the provincial public health information system. Between January 22 and February 22, 2020, there were 359 individuals who had a negative test result was recorded and three confirmed cases of COVID-19. Of those who tested negative, $51 \%$ were female and $71 \%$ were under 50 years of age. The most common symptoms reported were cough $(55 \%)$, fever $(37 \%)$ and sore throat $(35 \%)$. The majority were tested within three days of symptom onset, but over one-quarter tested more than seven days after symptom onset. Over the first month of reportability, reported travel history shifted from China to an increasing proportion with travel outside of China.
\end{abstract}

This work is licensed under a Creative Commons Attribution 4.0 International License.

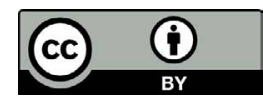

Affiliations

${ }^{1}$ Public Health Ontario, Toronto, ON

2 Dalla Lana School of Public Health, University of Toronto, Toronto, ON

${ }^{3}$ University of Toronto, Toronto, ON

\section{*Correspondence:}

michelle.murti@oahpp.ca persons who tested negative for COVID-19 in Ontario, January 22-February 22, 2020. Can Commun Dis Rep 2020;46(5):150-4. https://doi.org/10.14745/ccdr.v46i05a08

Keywords: coronavirus, COVID-19, surveillance, Ontario, testing

\section{Introduction}

In December 2019, the clinical syndrome caused by the severe acute respiratory syndrome coronavirus-2 (SARS-CoV-2) virus, (2019 coronavirus disease, COVID-19), was identified following an outbreak of pneumonia-like illness in Wuhan, China (1). Rapid identification of the virus causing the outbreak and development of diagnostic testing methods enabled countries around the world to test and identify cases within their borders (2). At the onset of the epidemic in China, Ontario alerted health care providers to the outbreak and recommended testing those with a travel history to Wuhan, China. As of January 22, 2020, "disease caused by a novel coronavirus" became reportable as a disease of public health significance in Ontario, and included case definitions for persons under investigation (PUI) and for probable, presumptive confirmed and confirmed cases $(3,4)$. In Ontario, local public health units are responsible for receiving notification of PUls undergoing testing for COVID-19, and for providing guidance on the public health management of individuals undergoing testing (5). On January 28, 2020, Public Health Ontario issued guidance to health units on the use of the integrated public health information system (iPHIS) for capturing information on PUls as well as cases. Subsequently, there has been global spread of COVID-19 and multiple introductions into Ontario and other parts of Canada (6), with the first case in Ontario reported on January 25.

Our goal is to describe public health surveillance data on individuals who were reported to public health, and who subsequently tested negative for COVID-19, in the first month after reportability was initiated in Ontario (January 22 to February 22, 2020).

\section{Situation: January-February, 2020}

Due to the rapidly evolving global epidemiology and understanding of COVID-19, there were several updates to the PUI case definition (Table 1), with expansion of affected areas to include all of mainland China and relaxation of symptom requirements. Clinical guidance on indications for testing also evolved and, as of February 22, all initial laboratory testing was conducted at Public Health Ontario $(5,7)$. Over this time period, both positive and negative test results for SARS-CoV-2 were being reported to the local Medical Officer of Health.

We examined COVID-19 records reported in iPHIS between January 22 and February 22, 2020. We excluded those meeting 
Table 1: Case definitions for persons under investigation in Ontario, January 22-February 22, 2020

\section{Date applicable}

Case definition version

\begin{tabular}{|c|c|}
\hline January 22-27, 2020 & $\begin{array}{l}\text { A person with fever and acute respiratory } \\
\text { illness, or pneumonia AND any of the } \\
\text { following: } \\
\text { - Travel to Wuhan, China in the } 14 \text { days } \\
\text { before onset of illness } \\
\text { OR } \\
\text { - Close contact }{ }^{\text {a }} \text { with a confirmed or } \\
\text { probable case of COVID-19 } \\
\text { OR } \\
\text { - Close contact with a person with acute } \\
\text { respiratory illness who has been to } \\
\text { Wuhan, China within } 14 \text { days prior to } \\
\text { their illness onset }\end{array}$ \\
\hline January 28-30, 2020 & $\begin{array}{l}\text { A person with fever and acute respiratory } \\
\text { illness, or pneumonia AND any of the } \\
\text { following: } \\
\text { - Travel to Hubei Province, China in the } \\
14 \text { days before onset of illness } \\
\text { OR } \\
\text { - Close contact with a confirmed or } \\
\text { probable case of COVID-19 } \\
\text { OR } \\
\text { - Close contact with a person with acute } \\
\text { respiratory illness who has been to } \\
\text { Hubei Province within } 14 \text { days prior to } \\
\text { their illness onset }\end{array}$ \\
\hline $\begin{array}{l}\text { January 31-February 7, } \\
2020\end{array}$ & $\begin{array}{l}\text { A person with fever and/or cough or } \\
\text { difficulty breathing AND any of the } \\
\text { following: } \\
\text { - Travel to Hubei Province, China in the } \\
14 \text { days before onset of illness } \\
\text { OR } \\
\text { - Close contact with a confirmed or } \\
\text { probable case of COVID-19 } \\
\text { OR } \\
\text { - Close contact with a person with acute } \\
\text { respiratory illness who has been to } \\
\text { Hubei Province within } 14 \text { days prior to } \\
\text { their illness onset }\end{array}$ \\
\hline February 8-26, 2020 & $\begin{array}{l}\text { A person with fever and/or cough or } \\
\text { difficulty breathing, AND any of the } \\
\text { following: } \\
\text { - Travel to mainland China in the } 14 \\
\text { days before onset of illness } \\
\text { OR } \\
\text { - Close contact with a confirmed or } \\
\text { probable case of COVID-19 } \\
\text { OR } \\
\text { - Close contact with a person with acute } \\
\text { respiratory illness who has been to } \\
\text { mainland China within } 14 \text { days prior to } \\
\text { their illness onset }\end{array}$ \\
\hline
\end{tabular}

A close contact is defined as a person who provided care for the patient, including healthcare workers, family members or other caregivers, or who had other similar close physical contact OR who lived with or otherwise had close prolonged contact with a probable or confirmed case while the case was ill the confirmed, presumptive confirmed or probable provincial case definition. These records included persons meeting the provincial case definition of a PUI at the time of report, persons with whom the local public health unit was following-up and persons for whom testing for COVID-19 had been performed and reported to the local public health unit $(n=466)$. Records without laboratory data in IPHIS were excluded from the analyses, leaving 359 records in our dataset. We evaluated the exposures, characteristics, symptoms and time between symptom onset and testing of these individuals. Exposures were assigned in a hierarchy of travel to China, travel outside of China and exposure in Ontario. All analyses were conducted using SAS Enterprise Guide v.7.1 (SAS Institute Inc., Cary, North Carolina).

The number of individuals with a negative test result peaked in mid-February with 29 individuals reported on February 10, 2020 (Figure 1). Travel to China was reported by the greatest number of patients $(n=196,54.6 \%)$ throughout the study period. After February 2, 2020, 32 patients reported travel outside of China.

Figure 1: Number of individuals who tested negative for COVID-19 ( $N=359)$, by date reported to the public health unit and place of exposure

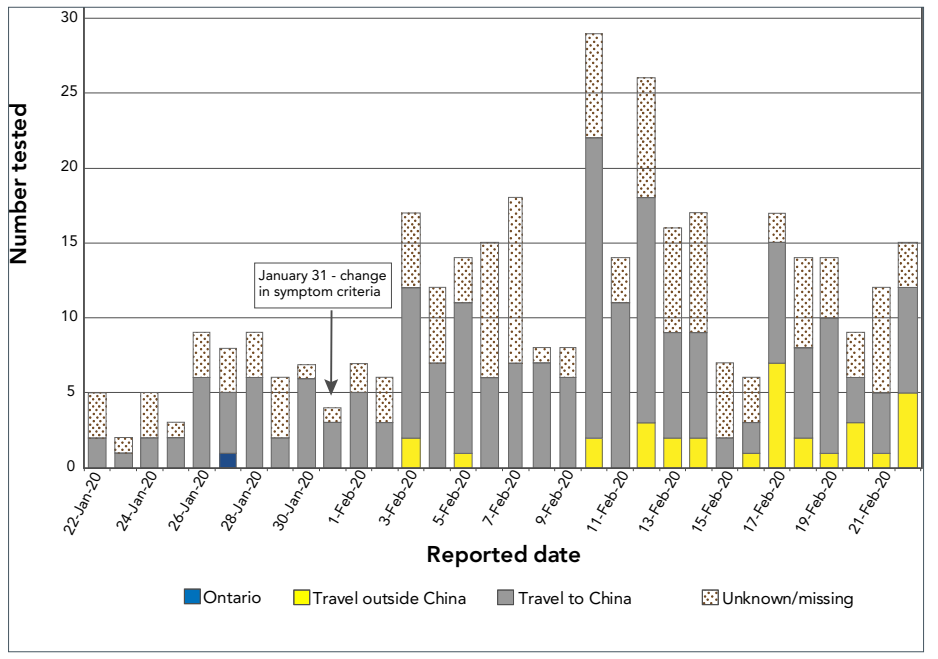

Just over half $(51.8 \%)$ of these patients were female. The majority $(71.3 \%)$ of the patients were younger than 50 years of age. The greatest number of the patients tested $(n=97,27.0 \%)$ were between the ages of 20 and 29 years. Among those younger than 10 years of age, $70.5 \%$ were male (Table 2). The most commonly reported symptoms among those with symptom data recorded $(n=314)$ were cough, fever and sore throat (Table 3$)$.

Among patients with specimen collection date within 30 days of symptom onset $(n=291 / 359,81.1 \%), 177$ (60.8\%) and 210 $(72.2 \%)$ were sampled within three and seven days of symptom onset, respectively. However, 81 (27.8\%) were sampled at least seven days after symptom onset and 23 (7.9\%) were collected between 14 and 30 days after symptom onset (Figure 2). 
Table 2: Age and gender of individuals who tested negative for COVID-19 ( $\mathrm{N}=359)$

\begin{tabular}{|l|r|r|r|r|}
\hline \multicolumn{1}{|c|}{$\begin{array}{c}\text { Age } \\
\text { group } \\
(n=186)\end{array}$} & $\begin{array}{c}\text { Females } \\
(n=168)\end{array}$ & $\begin{array}{c}\text { Mnspecified } \\
\text { gender } \\
\text { tested }(n=5)\end{array}$ & $\begin{array}{c}\text { Age } \\
\text { group } \\
\text { total } \\
(\mathrm{N}=359)\end{array}$ \\
\hline $\begin{array}{l}\text { Younger } \\
\text { than 10 } \\
\text { years }\end{array}$ & 13 & 31 & 0 & 44 \\
\hline $10-19$ years & 6 & 8 & 1 & 15 \\
\hline $20-29$ years & 56 & 40 & 1 & 97 \\
\hline $30-39$ years & 32 & 23 & 2 & 57 \\
\hline $40-49$ years & 25 & 18 & 0 & 43 \\
\hline $50-59$ years & 34 & 25 & 0 & 59 \\
\hline $60-69$ years & 16 & 16 & 0 & 32 \\
\hline $70-79$ years & 1 & 6 & 0 & 7 \\
\hline $80-89$ years & 3 & 1 & 1 & 5 \\
\hline a "Unspecified gender" includes gender listed as "other" (n=1) or "unknown" (n=4) \\
\hline
\end{tabular}

Table 3: Symptoms reported by individuals who tested negative for COVID-19 $(n=314)$

\begin{tabular}{|l|r|r|}
\multicolumn{1}{c|}{ Symptom } & \multicolumn{1}{c|}{$\begin{array}{c}\text { Numbers of } \\
\text { records }\end{array}$} & $\begin{array}{c}\text { Percentage of } \\
\text { patients reporting }\end{array}$ \\
\hline Cough & 171 & $54.5 \%$ \\
\hline Fever & 115 & $36.6 \%$ \\
\hline Sore throat & 109 & $34.7 \%$ \\
\hline Pain & 58 & $18.5 \%$ \\
\hline Shortness of breath & 47 & $15.0 \%$ \\
\hline Runny nose & 35 & $11.1 \%$ \\
\hline Chills & 21 & $6.7 \%$ \\
\hline Diarrhea & 20 & $6.4 \%$ \\
\hline Nausea & 7 & $2.2 \%$ \\
\hline Weakness & 1 & $0.3 \%$ \\
\hline Did not have symptom information for all cases
\end{tabular}

Figure 2: Number of days between the episode date and specimen collection $(n=291)^{\text {a }}$

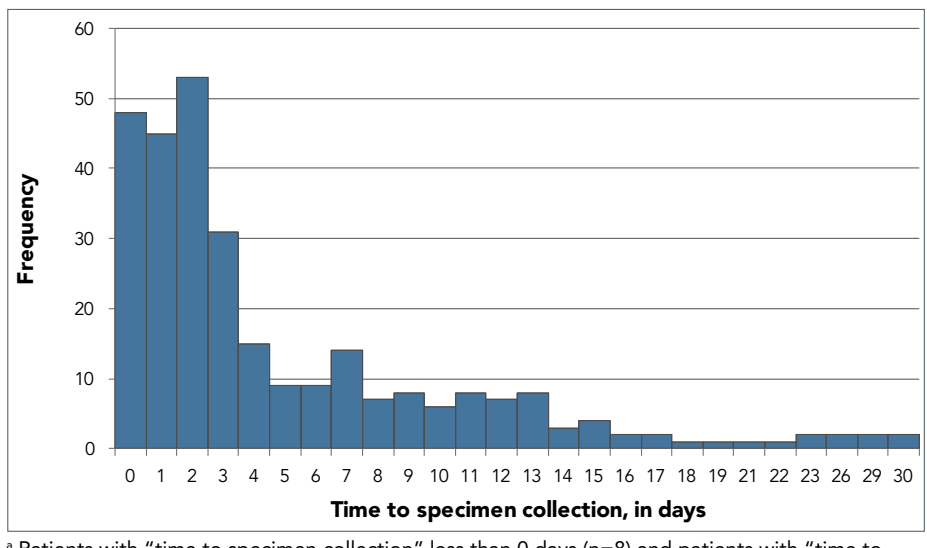

atients with "time to specimen collection" less than 0 days $(n=8)$ and patients with "time to specimen collection" greater than 30 days $(n=14)$ were excluded. Patients missing specimen date or symptom onset date $(n=46)$ were also excluded

\section{Discussion}

In the first month after reportability of COVID-19, there were 359 individuals with negative COVID-19 testing results recorded by public health units in the provincial surveillance system. In comparison, the United States Centers for Disease Control and Prevention reported across the country as of February 23 (8). By February 22, there were only three confirmed cases of COVID-19 in Ontario and all three of these cases had recently travelled to Wuhan, China.

The vast majority of those tested had a travel history to China, as expected, given the initial focus of exportation risk that was centered in Wuhan, China, and the exposure criteria of the PUI case definition. Travel bans were imposed by the city of Wuhan as of January 23, and these bans were extended progressively into other areas in China at the start of Lunar New Year (January 25, 2020) celebrations to slow the spread of the virus to other regions (9). Subsequently, beginning in early February, an increasing proportion of individuals in our analysis reported travel outside of China. By February 1, 2020, there were 7,153 cases in Hubei Province, 11,821 cases in China overall and 132 cases in 23 countries outside of China (10). As of February 26 , the case definition had been changed to include additional affected areas, which had further broadened the range of travel exposures reported (data not shown).

In our analysis, the demographics of persons testing negative in Ontario were younger compared with the age distribution of confirmed cases reported in China (11). However, the age groups for those tested in Ontario were similar to those for PUls assessed in the United States (12). The age structure of PUls in Ontario may be reflective of younger families and working age adults who had recently arrived from China or who had returned from visiting China, compared with elderly adults who may have been less likely to travel. Information on demographics of all returning travellers from China in this time period would be needed to assess this hypothesis.

As expected from the case definition, most cases reported cough or fever, similar to reports of PUls and cases in other jurisdictions where these are the two most common symptoms $(12,13)$. The third most common symptom amongst persons testing negative in Ontario was sore throat, with $34.7 \%$ of those with symptoms data reporting this symptom. In comparison, only $13.9 \%$ of 55,924 laboratory-confirmed cases in China reported a sore throat (13). Over the months of January and February, common seasonal respiratory viruses were circulating in the community, which may account for the higher prevalence of sore throat and may provide an alternative diagnoses of these individuals $(14,15)$. Despite lack of inclusion of gastrointestinal symptoms in the case definition, $6.4 \%$ of the individuals in our analysis reported diarrhea. Gastrointestinal symptoms were also reported in a minority of patients with COVID-19 in China $(13,16-19)$. 
There appears to be heightened awareness of the necessity for early assessment and testing as the majority of the persons in this study group presented for testing within three days of symptom onset. However, approximately one-quarter of persons tested waited for more than seven days prior to testing. With only three confirmed cases in this time period, we cannot reasonably compare symptom to testing behaviours of those who became positive. However, testing delays have implications for public health follow-up. Late testing may have missed detection of SARS-CoV-2 if individuals were already resolving their infection by the time testing occurred. Delays may be due to mild presentation of illness or heightened concern after symptom onset with increasing global awareness in this time period. This has implications for public health follow-up should these individuals eventually test positive, as there have been reports of transmissions from individuals in the presymptomatic phase of illness $(20,21)$.

With the changing global awareness of COVID-19, reevaluation of the delay from symptom onset to testing over time could inform evaluations of the effectiveness of public health messaging to immediately self-isolate and seek care/testing when symptoms start.

There are several limitations in our findings, which are inherent to public health surveillance data. Firstly, there are incomplete data in iPHIS on persons tested in the province due to individuals not being reported to local public health units, selective entry of individuals tested and incomplete entry of laboratory results into iPHIS. There may also be incomplete capture of symptoms and travel history depending on whether these were collected from the provider or the patient. Finally, there may be differential recall of symptoms and symptom onset among cases with a long time from symptom onset to testing.

\section{Conclusion}

Our surveillance findings demonstrate there was substantial testing of individuals identified in the first month after reportability in Ontario compared with other jurisdictions, as well as shifting epidemiology towards non-China travel exposures over time. Further assessment is needed on the relative importance of sore throat as a common symptom of persons tested, when sore throat has been less frequently described among cases in China. As well, further assessment is needed on reasons for extensive delays in testing from symptom onset among some individuals, as these delays may have significant implications for public health follow-up.

\section{Authors' statement}

$\mathrm{MW}$ and AS analyzed the data. KH oversaw the project. JG provided review of the data. MM and SB drafted the manuscript. All co-authors provided input on the final manuscript.

\section{Conflict of interest}

All authors have completed and submitted the International Committee of Medical Journal Editors (ICMJE) form for disclosure of potential conflicts of interest. No potential conflicts of interest were disclosed.

\section{Acknowledgements}

S Menon, Public Health Ontario, for formatting of manuscript.

\section{Funding}

This work was supported by Public Health Ontario.

\section{References}

1. World Health Organization. Coronovirus disease (COVID-19) Pandemic. Geneva, Switzerland: WHO; 2020. https://www. who.int/emergencies/diseases/novel-coronavirus-201

2. World ealth Organization. Coronavirus disease (COVID-19) technical guidance: Laboratory testing for 2019-nCoV in humans. Geneva, Switzerland: WHO; 2020. https://www. who.int/emergencies/diseases/novel-coronavirus-2019/ technical-guidance/laboratory-guidance

3. Ministry of Health. Infectious Diseases Protocol, Appendix A: Disease-Specific Chapters. Chapter: Diseases caused by a novel coronavirus, including Severe Acute Respiratory Syndrome (SARS) and Middle East Respiratory Syndrome (MERS). Toronto, ON: Queen's Printer for Ontario; 2020. http://www.health.gov.on.ca/en/pro/programs/publichealth/ oph_standards/docs/coronavirus_chapter.pdf

4. Ontario Ministry of Health and Ministry of Long-Term Care. Case Definition - Novel Coronavirus (COVID-19). Toronto, ON: Queen's Printer for Ontario; 2020. http://www.health. gov.on.ca/en/pro/programs/publichealth/coronavirus/ docs/2019_case_definition.pdf

5. Ontario Ministry of Health and Ministry of Long-Term Care. COVID-19: Guidance for the Health Sector. Toronto, ON: Queen's Printer for Ontario; 2020. http://www.health.gov. on.ca/en/pro/programs/publichealth/coronavirus/2019_ guidance.aspx

6. Public Health Agency of Canada. Coronavirus disease (COVID-19): Outbreak update. Ottawa, ON: Government of Canada; 2020. https://www.canada.ca/en/public-health/ services/diseases/2019-novel-coronavirus-infection.html

7. Ontario Agency for Health Protection and Promotion (Public Health Ontario). Coronavirus Disease 2019 (COVID-19) Testing. Toronto, ON: Queen's Printer for Ontario; 2020. https://www.publichealthontario.ca/en/laboratory-services/ test-information-index/wuhan-novel-coronavirus 
15. Ontario Agency for Health Protection and Promotion (Public Health Ontario). Laboratory Respiratory Pathogen Surveillance Reports. Toronto, ON: Queen's Printer for Ontario; 2020. https://www.publichealthontario.ca/en/ data-and-analysis/infectious-disease/laboratory-respirator y-pathogen-surveillance

16. Chen N, Zhou M, Dong $X$, Qu J, Gong F, Han Y, Qiu Y, Wang J, Liu Y, Wei Y, Xia J, Yu T, Zhang X, Zhang L. Epidemiological and clinical characteristics of 99 cases of 2019 novel coronavirus pneumonia in Wuhan, China: a descriptive study. Lancet 2020;395(10223):507-13. DOI PubMed

17. Huang C, Wang $Y$, Li $X$, Ren L, Zhao J, Hu Y, Zhang L, Fan G, Xu J, Gu X, Cheng Z, Yu T, Xia J, Wei Y, Wu W, Xie X, Yin W, Li H, Liu M, Xiao Y, Gao H, Guo L, Xie J, Wang G, Jiang R, Gao Z, Jin Q, Wang J, Cao B. Clinical features of patients infected with 2019 novel coronavirus in Wuhan, China. Lancet 2020;395(10223):497-506. DOI PubMed

18. Chan JF, Yuan S, Kok KH, To KK, Chu H, Yang J, Xing F, Liu J, Yip CC, Poon RW, Tsoi HW, Lo SK, Chan KH, Poon VK, Chan WM, Ip JD, Cai JP, Cheng VC, Chen H, Hui CK, Yuen KY. A familial cluster of pneumonia associated with the 2019 novel coronavirus indicating person-toperson transmission: a study of a family cluster. Lancet 2020;395(10223):514-23. DOI PubMed

19. Holshue ML, DeBolt $C$, Lindquist $\mathrm{S}$, Lofy $\mathrm{KH}$, Wiesman J, Bruce H, Spitters C, Ericson K, Wilkerson S, Tural A, Diaz G, Cohn A, Fox L, Patel A, Gerber SI, Kim L, Tong S, Lu X, Lindstrom S, Pallansch MA, Weldon WC, Biggs HM, Uyeki TM, Pillai SK; Washington State 2019-nCoV Case Investigation Team. First case of 2019 novel coronavirus in the United States. N Engl J Med 2020;382(10):929-36. DOI PubMed

20. Yu P, Zhu J, Zhang Z, Han Y, Huang L. A familial cluster of infection associated with the 2019 novel coronavirus indicating potential person-to-person transmission during the incubation period. J Infect Dis. 2020;jiaa077. DOI PubMed

21. Huang R, Xia J, Chen Y, Shan C, Wu C. A family cluster of SARS-CoV-2 infection involving 11 patients in Nanjing, China. Lancet Infect Dis. 2020;S1473-3099(20)30147-X. DOI PubMed 